\title{
YOGURT; A NOVEL EXCIPIENT (WITH ITS LYSED BACTERIA, AMINO ACIDS, VITAMINS, FATTY ACIDS, AND MINERALS) FOR “TOPICAL DERMATOLOGICAL PRODUCTS” AND FOR "SKIN MICROBIOTA"
}

\author{
M. ORHAN VAIZOGLU \\ ORVA Ilac A. S. and SEZA Kimyevi Ltd, AOSB, 10047 Sokak, No. 3, Cigli/Izmir/Turkey \\ Email: orhmuh@sezakimyevi.com.tr
}

Received: 25 Dec 2019, Revised and Accepted: 29 Jan 2020

\begin{abstract}
In recent years various Microbiomes (Skin, Gut Lumen) of the human body have attracted the attention of different research groups. In the meantime it has been shown that the conventional therapy of different diseases by making use of antibiotics and similar antibacterial treatments may disturb the harmony of the Skin Microbiome, resulting in dysbiosis. There are efforts of using "live" or "tyndallized (lysed)" probiotics in order to treat different diseases of the skin. It is also known that amino acids are one of the important key elements of the skin. In this paper, a hypothesis for the utilization of yogurt as an excipient for various topical dermatological products will be proposed. Yogurt contains significant amounts of; Probiotics (starter cultures), Amino Acids, Vitamins, Minerals and various Fatty Acids (saturated, monounsaturated and polyunsaturated). Besides, it has been shown that Antimicrobial Peptides (Bacteriocins) are also present in yogurt. Yogurt could eventually be used as an excipient for the production of various topical dermatological products in order to deliver some of the above-mentioned constituents to the Stratum Corneum (Skin) locally.
\end{abstract}

Keywords: Yogurt, Excipient, Dermatological, Topical, Microbiota

(C) 2020 The Authors. Published by Innovare Academic Sciences Pvt Ltd. This is an open-access article under the CC BY license (http://creativecommons.org/licenses/by/4.0/) DOI: http://dx.doi.org/10.22159/ijpps.2020v12i3.36704. Journal homepage: https://innovareacademics.in/journals/index.php/ijpps

\section{INTRODUCTION}

After exploration of the importance of Probiotic microorganisms like Lactobacillus species, Bifidobacterium species and their importance for "Human Gut Lumen Microbiota" and for "Skin Microbiota", scientific work upon this field is growing in an exponential manner. Because of the importance of probiotics for gut microbiota, and the importance of gut microbiota for human health and the immune system, probiotics attract the attention of many groups [1-10]. Different articles report interesting results, i.e. anti-cancer properties of bioactive peptides from synbiotic yogurt [5], antibacterial activity of bacteriocin isolated from lactobacillus bulgaricus [6], one article contemplates the probiotics as undervalued conquerors [8], one review article reports about the anti-aging properties of probiotics [9], another article reports about the role of gut microbiota in lipid metabolism, cholesterol levels and the positive effect of probiotics in infants with atopic dermatitis [10]. Since yogurt also contains probiotics, it can eventually be an important candidate as an excipient for various topical dermatological products. As an example of utilizing yogurt as a major excipient for topical dermatological products, we are working on a topical ointment using yogurt as one of the main excipients, in excess of $50 \%$. Besides yogurt, Dexpanthenol, Olive Oil, Almond Oil and other necessary ingredients for emulsion formation and antimicrobial agents are being used. The resulting ointment has acceptable organoleptic, microbiological, physicalchemical properties and stability (unpublished results). It has been reported by different authors, that probiotic bacteria are lysed by heat at elevated temperatures $\left(70-100^{\circ} \mathrm{C}\right)$. Following the lysation of probiotic bacteria, favorable cell contents for the skin microbiome, including Antimicrobial Peptides (Bacteriocins) are excreted [4-6]. Recent studies report that Antimicrobial Peptides (Bacteriocins) are also present in yogurt, which seem to be stable at elevated temperatures, i.e. $80^{\circ} \mathrm{C}$ [6]. It has also been shown by different publications and patents that the "lysates" of probiotics are at least as effective as their "live" forms in inhibiting various pathogenic bacteria, either in the gut lumen and/or skin surface [7, 11-14]. The conventional method of manufacturing topical dermatological products is performed at elevated temperatures (i.e. $80{ }^{\circ} \mathrm{C}$ ) and under turbulent homogenization. Considering the fact that probiotic bacteria would be lysed at elevated temperatures, it is highly probable that the probiotics in yogurt, when yogurt is used as an excipient for topical dermatological products, should also be in the lysed form following the production of the corresponding ointment. Besides, the added antimicrobial agents would also be contributing to this lysation process. Not to be forgotten is the fact that yogurt is not only rich in probiotics. Besides probiotic bacteria, yogurt is rich in Amino Acids (amino acids make up $40 \%$ of the skin's Natural Moisturizing Factor/NMF) [15], Vitamins, Fatty Acids, and Minerals [16]. It can be assumed that only very small fractions of Amino Acids, Vitamins, Fatty Acids and Minerals will reach the skin surface following systemic application of these ingredients in various dosage forms. In case the skin, i.e. the Stratum Corneum is directly targeted, yogurt could eventually be used as an excipient for various topical dermatological products, for supplying the skin with; Lysed Probiotic Bacteria, Amino Acids, Vitamins, Fatty Acids and Minerals, locally. It seems as if there is quite some work to be done upon this field.

Hypothesis

Yogurt

The word "yogurt" is a Turkish word. It is believed to have come from the word "yoğurmak" which means to thicken, coagulate and curdle $[17,18]$. Yogurt is a fermented milk product. Following fermentation, the main structure of yogurt consists of a casein gel. In between, there are empty spaces filled with a liquid phase known as whey, which is the liquid part of milk left after fermentation. Some of these spaces are filled with starter bacteria [1]. The main starter cultures/bacteria which are used for the production of yogurt are; "Streptococcus thermophilus" and "Lactobacillus bulgaricus". S. thermophilus is an aerobic and L. bulgaricus an anaerobic bacterium $[1,2,17,18]$. Both bacteria cooperate for the fermentation of milk. As a result, from lactose in milk, lactic acid is produced. The $\mathrm{pH}$ will be more acidic, where the growth of other bacteria is unfavored. During this cooperation, $S$. thermophilus produces pyruvic acid, formic acid and carbon dioxide, which in turn stimulate the growth of $L$. bulgaricus. $L$. bulgaricus produces peptides and amino acids which promote the growth of $S$. thermophilus [19]. According to 
FAO/WHO, these two bacteria fulfill the definition of probiotic bacteria. FAO/WHO defines Probiotics as; "live microorganisms, which when administered in adequate amounts, confer a health benefit on the host" [3]. According to Guarner et al. [20], taken here "word by word" from the corresponding publication; "a number of human studies have clearly demonstrated that yoghurt containing viable bacteria (Streptococcus thermophilus and Lactobacillus delbrueckii sp. Bulgaricus) improve lactose digestion and eliminate symptoms of lactose intolerance. Thus, these cultured bacteria clearly fulfill the current concept of probiotics".

\section{Nutrient composition of yogurt}

USDA National Nutrient Database for Standard Reference [16], has reported the nutrient composition of "Plain Yogurt/Whole Milk" in its "4/1/2019 Release". The relevant nutrients, excluding the ones under the title "Others", are presented in table 1. Besides nutrients, yogurt contains probiotics like "S. thermophilus" and " $L$. bulgaricus". Antimicrobial Peptides (Bacteriocins) are also identified in yogurt, which seems to be stable at elevated temperatures, i.e. $80^{\circ} \mathrm{C}[4-6]$.

Table 1: Nutritional value of plain, whole milk yogurt. From USDA. Composition of Yogurt/nutrients in 100g

\begin{tabular}{|c|c|c|c|c|}
\hline Proximates & $100 \mathrm{~g}$ & Amino acids & $100 \mathrm{~g}$ & Reference \\
\hline Water & $87,90 \mathrm{~g}$ & Tryptophan & $0,020 \mathrm{~g}$ & [16] \\
\hline Protein & $3,47 \mathrm{~g}$ & Threonine & $0,142 \mathrm{~g}$ & \\
\hline Total Lipid (Fat) & $3,25 \mathrm{~g}$ & Isoleucine & $0,189 \mathrm{~g}$ & \\
\hline Carbohydrate & $4,66 \mathrm{~g}$ & Leucine & $0,350 \mathrm{~g}$ & \\
\hline \multirow[t]{2}{*}{ Sugars } & $4,66 \mathrm{~g}$ & Lysine & $0,311 \mathrm{~g}$ & \\
\hline & & Methionine & $0,102 \mathrm{~g}$ & \\
\hline Minerals & $100 \mathrm{~g}$ & Cystine & $0,032 \mathrm{~g}$ & \\
\hline Calcium, $\mathrm{Ca}$ & $121 \mathrm{mg}$ & Phenylalanine & $0,189 \mathrm{~g}$ & \\
\hline Iron, Fe & $0,05 \mathrm{mg}$ & Tyrosine & $0,175 \mathrm{~g}$ & \\
\hline Magnesium, Mg & $12 \mathrm{mg}$ & Valine & $0,287 \mathrm{~g}$ & \\
\hline Phosphorus, P & $95 \mathrm{mg}$ & Arginine & $0,104 \mathrm{~g}$ & \\
\hline Potassium, K & $155 \mathrm{mg}$ & Histidine & $0,086 \mathrm{~g}$ & \\
\hline Sodium, $\mathrm{Na}$ & $46 \mathrm{mg}$ & Alanine & $0,148 \mathrm{~g}$ & \\
\hline Zinc, Zn & $0,59 \mathrm{mg}$ & Aspartic acid & $0,275 \mathrm{~g}$ & \\
\hline Copper, Cu & $0,009 \mathrm{mg}$ & Glutamic acid & $0,679 \mathrm{~g}$ & \\
\hline Manganese, Mn & $0,004 \mathrm{mg}$ & Glycine & $0,084 \mathrm{~g}$ & \\
\hline Selenium, Se & $2,2 \mu \mathrm{g}$ & Proline & $0,411 \mathrm{~g}$ & \\
\hline Fluroride, F & $12 \mu \mathrm{g}$ & Serine & $0,215 \mathrm{~g}$ & \\
\hline Vitamins & $100 \mathrm{~g}$ & Lipids & $100 \mathrm{~g}$ & \\
\hline Vit C (total Ascorbic acid) & $0,5 \mathrm{mg}$ & Fatty acids, total saturated & $2,096 \mathrm{~g}$ & \\
\hline Thiamin, Vit B1 & $0,029 \mathrm{mg}$ & $4: 0$ & $0,096 \mathrm{~g}$ & \\
\hline Riboflavin & $0,142 \mathrm{mg}$ & $6: 0$ & $0,066 \mathrm{~g}$ & \\
\hline Niacin & $0,075 \mathrm{mg}$ & $8: 0$ & $0,042 \mathrm{~g}$ & \\
\hline Panthotenic acid & $0,389 \mathrm{mg}$ & $10: 0$ & $0,093 \mathrm{~g}$ & \\
\hline Vit B6 & $0,032 \mathrm{mg}$ & $12: 0$ & $0,111 \mathrm{~g}$ & \\
\hline Folate Total & $7 \mu \mathrm{g}$ & $14: 0$ & $0,343 \mathrm{~g}$ & \\
\hline Carotene, beta & $5 \mu \mathrm{g}$ & $16: 0$ & $0,886 \mathrm{~g}$ & \\
\hline Choline Total & $15,2 \mathrm{mg}$ & $18: 0$ & $0,317 \mathrm{~g}$ & \\
\hline Vit B12 & $0,37 \mu \mathrm{g}$ & Fatty acids, total monounsaturated & $0,893 \mathrm{~g}$ & \\
\hline Retinol & $27 \mu \mathrm{g}$ & $16: 1$ & $0,071 \mathrm{~g}$ & \\
\hline Vit A, RAE & $27 \mu \mathrm{g}$ & $18: 1$ & $0,743 \mathrm{~g}$ & \\
\hline Vit E, (alpha-tocopherol) & $0,06 \mathrm{mg}$ & $20: 1$ & 0 & \\
\hline Vit D (D2+D3) & $0,1 \mu \mathrm{g}$ & $22: 1$ & 0 & \\
\hline Vit D3 (cholecalciferol) & $0,1 \mu \mathrm{g}$ & & & \\
\hline Vit D & $2 \mathrm{IU}$ & Fatty acids, total polyunsaturated & $0,092 \mathrm{~g}$ & \\
\hline Vit K (phylloquinone) & $0,2 \mu \mathrm{g}$ & $18: 2$ & $0,065 \mathrm{~g}$ & \\
\hline & & $18: 3$ & $0,027 \mathrm{~g}$ & \\
\hline & & $18: 4$ & 0 & \\
\hline & & $20: 4$ & 0 & \\
\hline & & $20: 5$ n-3 (EPA) & 0 & \\
\hline & & $22: 5 n-3(D P A)$ & 0 & \\
\hline & & $22: 6$ n-3 (DHA) & 0 & \\
\hline & & Cholesterol & $13 \mathrm{mg}$ & \\
\hline
\end{tabular}

Considering yogurt as an excipient for various topical dermatological products from the aspect of amino acids, vitamins, and minerals

As an example of utilizing yogurt as an excipient for topical dermatological products, we are working on a topical ointment using yogurt as the main excipient, in excess of 50\%. Besides Yogurt, Dexpanthenol, Olive Oil, Almond Oil, and Antimicrobial Agents, other necessary ingredients for emulsion formation are being used. The resulting ointment has acceptable organoleptic, physical-chemical, microbiological properties and stability (unpublished results). For the sake of simplicity, let us consider that we use, besides other necessary ingredients for emulsion formation and antimicrobials, $50 \% / 50 \mathrm{~g}$ yogurt in a $100 \mathrm{~g}$ ointment. We can then, depending on table 1, calculate the amount of amino acids, vitamins, minerals and lipids which would be present in such a formulation (excluding the lipids coming from the other ingredients). In table 2, the amount of nutrients in $50 \mathrm{~g}$ yogurt are also calculated depending on the data of USDA [16]. Since we aim at using 50\%/50g yogurt in our hypothetical formulation, the nutrients which are present in $50 \mathrm{~g}$ yogurt should be present in our $100 \mathrm{~g}$ hypothetical formulation. In our preliminary studies, we were able to reassess the amount of amino acids in our finished topical formulation, which was proportional to the amounts of amino acids in the yogurt sample 
used (unpublished results). We have "not" done similar studies for the vitamins, minerals and lipids. In the corresponding columns of table 2, depending on the data of USDA [16], the amount of amino acids, minerals, vitamins, and lipids which would be present in $1 \mathrm{~g}$ of the above mentioned hypothetical $100 \mathrm{~g}$ ointment are calculated. $1 \mathrm{~g}$ ointment also corresponds to 2 Finger Tip Units (FTU). The details for FTU for an adult male fingertip is given below [21]:

Table 2: Amount of nutrients in $50 \mathrm{~g}$ yogurt and in $1 \mathrm{~g} \mathrm{(2} \mathrm{FTU)} \mathrm{of} \mathrm{a} \mathrm{hypothetical} \mathrm{ointment} \mathrm{containing} \mathrm{50 \% /50g} \mathrm{yogurt.} \mathrm{The} \mathrm{amounts} \mathrm{are}$ calculated depending on the yogurt data of USDA, from table 1

\begin{tabular}{|c|c|c|c|c|c|c|}
\hline Minerals & $50 \mathrm{~g}$ & 1g Ointment (2FTU) & Amino acids & $50 \mathrm{~g}$ & 1g Ointment (2 FTU) & Reference \\
\hline Calcium, $\mathrm{Ca}$ & $60,5 \mathrm{mg}$ & $605 \mu \mathrm{g}$ & Tryptophan & $0,010 \mathrm{~g}$ & $100 \mu \mathrm{g}$ & [16] \\
\hline Iron, $\mathrm{Fe}$ & $0,025 \mathrm{mg}$ & $0.25 \mu \mathrm{g}$ & Threonine & $0,71 \mathrm{~g}$ & $7100 \mu \mathrm{g}$ & \\
\hline Magnesium, Mg & $6 \mathrm{mg}$ & $60 \mu \mathrm{g}$ & Isoleucine & $0,0945 \mathrm{~g}$ & $945 \mu \mathrm{g}$ & \\
\hline Phosphorus, $\mathrm{P}$ & $47,5 \mathrm{mg}$ & $475 \mu \mathrm{g}$ & Leucine & 0,175 & $1750 \mu \mathrm{g}$ & \\
\hline Potassium, K & $77,5 \mathrm{mg}$ & $775 \mu \mathrm{g}$ & Lysine & $0,1555 \mathrm{~g}$ & $1555 \mu \mathrm{g}$ & \\
\hline Sodium, $\mathrm{Na}$ & $23 \mathrm{mg}$ & $230 \mu \mathrm{g}$ & Methionine & $0,051 \mathrm{~g}$ & $510 \mu \mathrm{g}$ & \\
\hline Zinc, Zn & $0,295 \mathrm{mg}$ & $2.95 \mu \mathrm{g}$ & Cystine & $0,016 \mathrm{~g}$ & $160 \mu \mathrm{g}$ & \\
\hline Copper, $\mathrm{Cu}$ & $0,0045 \mathrm{mg}$ & $0.045 \mu \mathrm{g}$ & Phenylalanine & $0,0945 \mathrm{~g}$ & $945 \mu \mathrm{g}$ & \\
\hline Manganese, Mn & $0,002 \mathrm{mg}$ & $0.02 \mu \mathrm{g}$ & Tyrosine & $0,0875 \mathrm{~g}$ & $875 \mu \mathrm{g}$ & \\
\hline Selenium, Se & $1,1 \mu \mathrm{g}$ & $0.011 \mu \mathrm{g}$ & Valine & $0,1435 \mathrm{~g}$ & $1435 \mu \mathrm{g}$ & \\
\hline Fluroride, F & $6 \mu \mathrm{g}$ & $0.06 \mu \mathrm{g}$ & Arginine & $0,052 \mathrm{~g}$ & $520 \mu \mathrm{g}$ & \\
\hline Vitamins & $50 \mathrm{~g}$ & 1g Ointment ( 2 FTU) & Histidine & $0,043 \mathrm{~g}$ & $430 \mu \mathrm{g}$ & \\
\hline Vit C (total Ascorbic acid) & $0,25 \mathrm{mg}$ & $2.5 \mu \mathrm{g}$ & Alanine & $0,074 \mathrm{~g}$ & $740 \mu \mathrm{g}$ & \\
\hline Thiamin, Vit B1 & $0,0145 \mathrm{mg}$ & $0,145 \mu \mathrm{g}$ & Aspartic acid & $0,1375 \mathrm{~g}$ & $1375 \mu \mathrm{g}$ & \\
\hline Riboflavin & $0,071 \mathrm{mg}$ & $0.71 \mu \mathrm{g}$ & Glutamic acid & $0,3395 \mathrm{~g}$ & $3395 \mu \mathrm{g}$ & \\
\hline Niacin & $0,0375 \mathrm{mg}$ & $0,375 \mu \mathrm{g}$ & Glycine & $0,042 \mathrm{~g}$ & $420 \mu \mathrm{g}$ & \\
\hline Panthotenic acid & $0,1945 \mathrm{mg}$ & $1.945 \mu \mathrm{g}$ & Proline & $0,2055 \mathrm{~g}$ & $2055 \mu \mathrm{g}$ & \\
\hline Vit B6 & $0,016 \mathrm{mg}$ & $0,16 \mu \mathrm{g}$ & Serine & $0,1075 \mathrm{~g}$ & $1075 \mu \mathrm{g}$ & \\
\hline Folate Total & $3,5 \mu \mathrm{g}$ & $0,035 \mu \mathrm{g}$ & Lipids & $50 \mathrm{~g}$ & 1g Ointment (2 FTU) & \\
\hline Folic acid & 0 & 0 & $\begin{array}{l}\text { Fatty acids, total } \\
\text { saturated }\end{array}$ & $1,048 \mathrm{~g}$ & $10480 \mu \mathrm{g}$ & \\
\hline Choline & $7,6 \mathrm{mg}$ & $76 \mu \mathrm{g}$ & $4: 0$ & $0,048 \mathrm{~g}$ & $480 \mu \mathrm{g}$ & \\
\hline Vit B12 & $0,185 \mu \mathrm{g}$ & $0,00185 \mu \mathrm{g}$ & $6: 0$ & $0,033 \mathrm{~g}$ & $330 \mu \mathrm{g}$ & \\
\hline Retinol & $13,5 \mu \mathrm{g}$ & $0,135 \mu \mathrm{g}$ & 8:0 & $0,021 \mathrm{~g}$ & $210 \mu \mathrm{g}$ & \\
\hline Vit A, IU & $49,5 \mathrm{IU}$ & $0,495 \mathrm{IU}$ & $10: 0$ & $0,0465 \mathrm{~g}$ & $465 \mu \mathrm{g}$ & \\
\hline Vit E, (alpha-tocopherol) & $0,03 \mathrm{mg}$ & $0,3 \mu \mathrm{g}$ & $12: 0$ & $0,0555 \mathrm{~g}$ & $555 \mu \mathrm{g}$ & \\
\hline Vit D (D2+D3) & $0,05 \mu \mathrm{g}$ & $0,0005 \mu \mathrm{g}$ & $14: 0$ & $0,1715 \mathrm{~g}$ & $1715 \mu \mathrm{g}$ & \\
\hline Vit D3 (cholecalciferol) & $0,05 \mu \mathrm{g}$ & $0,0005 \mu \mathrm{g}$ & $16: 0$ & $0,443 \mathrm{~g}$ & $4430 \mu \mathrm{g}$ & \\
\hline Vit D & $1 \mathrm{IU}$ & $0,01 \mathrm{IU}$ & $18: 0$ & $0,1585 \mathrm{~g}$ & $1585 \mu \mathrm{g}$ & \\
\hline \multirow[t]{14}{*}{ Vit K (phylloquinone) } & $0,1 \mu \mathrm{g}$ & $0,001 \mu \mathrm{g}$ & $\begin{array}{l}\text { Fatty acids, total } \\
\text { monounsaturated }\end{array}$ & $0,4465 \mathrm{~g}$ & $4465 \mu \mathrm{g}$ & \\
\hline & & & $\begin{array}{l}\text { 16:1 } \\
\text { undifferentiated }\end{array}$ & $0,0355 \mathrm{~g}$ & $355 \mu \mathrm{g}$ & \\
\hline & & & $\begin{array}{l}\text { 18:1 } \\
\text { undifferentiated }\end{array}$ & $0,3715 \mathrm{~g}$ & $3715 \mu \mathrm{g}$ & \\
\hline & & & $20: 1$ & 0 & 0 & \\
\hline & & & $\begin{array}{l}22: 1 \\
\text { undifferentiated }\end{array}$ & 0 & 0 & \\
\hline & & & $\begin{array}{l}\text { Fatty acids, total } \\
\text { polyunsaturated }\end{array}$ & $0,046 \mathrm{~g}$ & $460 \mu \mathrm{g}$ & \\
\hline & & & $\begin{array}{l}18: 2 \\
\text { undifferentiated }\end{array}$ & $0,0325 \mathrm{~g}$ & $325 \mu \mathrm{g}$ & \\
\hline & & & $\begin{array}{l}18: 3 \\
\text { undifferentiated }\end{array}$ & $0,0135 \mathrm{~g}$ & $135 \mu \mathrm{g}$ & \\
\hline & & & $18: 4$ & 0 & 0 & \\
\hline & & & $\begin{array}{l}20: 4 \\
\text { undifferentiated }\end{array}$ & 0 & 0 & \\
\hline & & & $20: 5 n-3(E P A)$ & 0 & 0 & \\
\hline & & & $22: 5$ n-3 (DPA) & 0 & 0 & \\
\hline & & & $22: 6 n-3(D H A)$ & 0 & 0 & \\
\hline & & & Cholesterol & $6,5 \mathrm{mg}$ & $65 \mu \mathrm{g}$ & \\
\hline
\end{tabular}

The quantity of cream in a Finger Tip Unit (FTU) varies with age [21]:

- $\quad$ Adult male: 1 finger-tip unit provides $0.5 \mathrm{~g}$

The necessary FTU for different body areas are given below [21]:

- $\quad$ One hand 1 FTU

- $\quad$ One arm 3 FTU

- $\quad$ One foot 2 FTU

- $\quad$ One leg 6 FTU

\section{- $\quad$ Face and neck 2,5 FTU \\ - $\quad$ Trunk, front and back 14 FTU \\ - $\quad$ Entire body about 40 FTU}

Supposing that we would like to use the hypothetical ointment for the treatment of "One Adult Foot".

We would then need 2 FTU=1g ointment, as expressed above. The corresponding amount of nutrients that would be delivered by the hypothetical $1 \mathrm{~g}$ ointment are shown in table 2. 
Questions about the fraction of an amino acid dose reaching the stratum corneum following systemic application

Amino acids are, among others, breakdown products of filaggrin which is important for proper epidermal differentiation and skin barrier function.
The amino acids and the other byproducts of filaggrin contribute to the formation of the Natural Moisturizing Factor (NMF) [22] as shown in table 3 [15]. The Confocal Raman Spectroscopy depth measurements indicate that the $N M F$ concentration is higher in the whole Stratum Corneum of the human skin [23].

Table 3: Chemical composition of the Natural Moisturizing Factor/NMF

\begin{tabular}{ll}
\hline Free Amino Acids & $40 \%$ \\
Pyrrollidone carboxylic acid & $12 \%$ \\
Lactate & $12 \%$ \\
Sugars & $8,5 \%$ \\
Urea & $7 \%$ \\
Chloride & $6 \%$ \\
Sodium & $5 \%$ \\
Potassium & $4 \%$ \\
Ammonia, uric acid, glucosamine and creatine & $1,5 \%$ \\
Calcium & $1,5 \%$ \\
Magnesium & $1,5 \%$ \\
Phosphate & $0,5 \%$ \\
Citrate, formate & $0,5 \%$ \\
\hline
\end{tabular}

As far as our surveys about the data in the scientific literature are concerned, we do not know what fraction of a systemically applied amino acid dose would reach the Skin/Stratum Corneum. For many drugs, the term Volume of Distribution (pharmacokinetics) is used as a calculation factor to approximately calculate the amount of drug in the body at any time, by making use of i.e. plasma concentrations. As an example, let us take the Volume of Distribution of the amino acid Arginine, which is given to be around 24 liters, assessed in humans. The authors [24] have infused $3 \mathrm{~g}$ of L-Arginine to humans and have measured "peak plasma concentrations" of approximately $400 \mu$ moles/liter, which corresponds to approximately $70 \mu \mathrm{g} / \mathrm{ml}$ for L-Arginine.

The U. S. Food and Nutrition Board has published the Recommended Dietary Allowances for various amino acids for adults. Depending on the type of amino acid, the amounts vary between 8-14 mg per $\mathrm{kg}$ of body weight [25]. If we consider an average value of $10 \mathrm{mg} / \mathrm{kg}$ allowance for a certain amino acid, for an average person of $75 \mathrm{~kg}$ body weight, the total dietary allowance would be around $0,75 \mathrm{~g}$. As cited above, after an infusion of 3g L-Arginine, the peak plasma concentrations are measured to be approximately $70 \mu \mathrm{g} / \mathrm{ml}$ [24]. After systemic application of $0,75 \mathrm{~g}$ amino acid, the plasma concentrations should be considerably lower (assuming 100\% bioavailability and no "first-pass-effect" following peroral application). It can be assumed that only very small fractions of the amount present in the plasma would reach the Skin Surface/Stratum Corneum.

Looking at table 2, it can be seen that relative significant amounts of amino acids can be delivered locally to the stratum corneum by utilization of yogurt as an-excipient in a topical dermatological product.

Amino acids make up $40 \%$ of the skin's Natural Moisturizing Factor/NMF. The other constituents of the NMF besides amino acids are given in table 3 [15]. One could eventually achieve significant moisturization of the skin by delivering amino acids, minerals, and the humectant lactic acid (which is one of the major constituents of yogurt) by means of a topical yogurt containing ointment locally.

As shown in table 1 , besides amino acids, yogurt also contains significant amounts of vitamins, minerals, and lipids. We have not studied the fate and proportional transfer of vitamins, minerals, and lipids from the yogurt samples used. They may or may not have been degraded during the manufacturing process. There seems to be quite some work to be done upon this field.

Considering yogurt as an excipient for topical dermatological products from the aspect of lysed probiotics

\section{The skin Microbiome}

Since the Skin Microbiome is the main scope of this paper, various other Microbiomes of the human body will not be discussed.
In their very interesting paper, Grice and Segre [26], have presented the schematic of the skin histology in a cross-sectional form. Microorganisms, like viruses, bacteria, and fungi are schematized on the surface of the skin, which also reside in sweat glands, sebaceous glands, hair and hair shaft. Rod-shaped and round bacteria, like Proteobacteria and Staphylococcus spp., commensal fungi like Malassezia spp. and skin mites (i.e. Demodex folliculorum, Demodex brevis) are also schematized for the reader in a brilliant and very understandable scheme. All these microorganisms live in communities and in close association with each other. Major examples of the 19 phyla which are known to be part of the skin microbiome are; Actinobacteria (51, 8\%), Firmicutes (24, 4\%), Proteobacteria $(16,5 \%)$ and Bacteriodetes. The major genera are Corynebacterium, Propionibacterium, and Staphylococcus [27]. The skin is an ecosystem of, microorganisms and host, existing in balance and harmony. The disturbance of this homeostasis may lead to different diseases [26, 27]. On the other hand, this homeostasis may also be misbalanced by exogenous agents, used for the treatment of various dermatological disorders. This should perhaps lead us to reevaluate our understanding of treating various diseases, i.e. the unnecessary use of antibiotics, which may disturb the microbiome balance and harmony, resulting in dysbiosis. In such cases, it may take long periods for the microbiome to recover [27, 28].

\section{Use of lysed probiotics and their effect on the skin}

It has been shown by different publications and patents that the "lysates" of probiotics are at least as effective as their "live" forms in inhibiting various pathogenic bacteria, either in the Gut Lumen and/or Skin Surface [7, 11-14, 29, 30].

Since it is not the scope of this paper to discuss the effects of "live probiotics" on the skin microbiome, solely the effect of "lysed probiotics" will be discussed. As already implemented above, FAO/WHO defines Probiotics as; "live microorganisms, which when administered in adequate amounts, confer a health benefit on the host" [3]. According to Guarner et al. [20], taken here from the corresponding publication "word by word"; "a number of human studies have clearly demonstrated that yoghurt, containing viable bacteria (Streptococcus thermophilus and Lactobacillus delbrueckii $s p$. Bulgaricus), improve lactose digestion and eliminate symptoms of lactose intolerance. Thus, these cultured bacteria clearly fulfill the current concept of probiotics".

Pique et al. mention different methods for the inactivation/lysation of probiotic bacteria. The mentioned methods are; heat $\left(70-100{ }^{\circ} \mathrm{C}\right)$, chemicals like formalin, gamma or ultraviolet rays and sonication. The preferred method being heat inactivation. Inactivation ruptures the cell walls of the probiotic bacteria, thereby releasing the cytoplasmic contents, i.e.; DNA and cell wall components like Peptidoglycans, Lipoteichoic acids or heat-labile Pilli. They cite that the excreted components play key immunomodulating roles, i.e. 
production of IgA by "S. thermophilus lysates" and anti-inflammatory responses mediated by metabolites and cell surfaces of " $L$. delbrueckii". The authors cite that the lysate components of heat-killed probiotics would inhibit pathogens and also release Antimicrobial Peptides (Bacteriocins) which are effective against Gram-positive and Gram-negative bacteria [11]. Lew and Liong cite that the cell wall fragments of probiotic bacterial extracts, their metabolites and the dead probiotic bacteria as such, can improve skin barrier functions and regulate immune responses. One of the components of lysed $S$. thermophilus, the Sphingomyelinase enzyme, when applied in cream was able to increase the ceramide levels on the volar forearm of healthy human volunteers significantly $(\mathrm{p}<0.05)$ within a week. Other cell components, like Lipoteichoic acid, increases dermal cellular defense against bacterial infection and Peptidoglycan plays an important role in defending the skin against pathogens [12].

Shigwedha et al. name the "probiotical cell fragments (PCFs)" of probiotics as "parabiotics" since they do not represent intact bacteria. They also cite that the cell components of such bacteria, i.e. Peptidoglycan, Lipoteichoic acid, cell wall-associated Polysaccharides, Muramyl peptide, Muramyl dipeptide, when applied intestinally would exert beneficial effects. They mention that these cell fragments inhibit the adhesion of $C$. perfringens, $E$. coli, $S$. thyphimurium, C. difficile, Shigella sp. and Salmonella sp. to mucus and/or intestinal epithelial cells in a competitive way [7].

Di Marzio et al. have shown that sonicated (lysed) S. thermophilus strains, "which is one of the starter bacteria for yogurt", when applied topically to patients suffering from atopic dermatitis, increased the level of ceramides in the stratum corneum thereby improving barrier function [29].

In one patent application [30], the inventors describe the use of lysed probiotic bacteria against skin infections. Lysates of Lactobacillus rhamnosus GG, was shown to inhibit Staphylococcus aureus infection by preventing the adhesion of St. aureus to cells. They also cite that these lysates can be administered in different dosage forms, including liposomes and other microparticulate dosage forms.

In a thesis submitted to the University of Manchester Medical Faculty, it is cited that lysates of Lactobacillus rhamnosus $G G$ was effective against the adhesion of St. aureus to keratinocytes thereby counteracting infections. It has also been shown that $L$. rhamnosus $G G$ lysates also enhance the re-epithelization of wounds, favoring keratinocyte terminal differentiation. The study cites that $L$. rhamnosus $G G$ lysates can be used as a therapeutic agent to enhance wound healing [13].

Gueniche et al., cite that lysates of Bifidobacterium longum spp. would improve sensitive skin. Skin sensitivity was assessed by the stinging test. Following barrier disruption, skin recovery was evaluated by measuring the Trans-Epidermal Water Loss (TEWL), in a double-blind, randomized, placebo-controlled trial, where a $10 \%$ cream of $B$. longum spp. lysate was applied. The results show that the volunteers who used the extract in a cream form had a significant drop in skin sensitivity and a significant decrease in skin dryness at the end of the treatment [14].

Tufail et al., isolated Bacteriocins (Antimicrobial Peptides) from Lactobacillus bulgaricus (which is one of the starter cultures of yogurt) and tested the inhibitory activity against B. subtilis, E. coli, $S$. typhi, St. aureus, $V$. cholerae by use of the agar diffusion method. They cite that the isolates have antibacterial potential against the mentioned pathogens [6].

To give the reader a picture about the amount of "L. bulgaricus and $S$. thermophilus" in yogurt, which are the main probiotics (starter bacteria) for yogurt production, the viable bacterial counts in yogurt are given below in table 4 .

Table 4: The viable bacterial counts in Yogurt $[2,31]$

\begin{tabular}{lll}
\hline Yilmaz-Ersan L, Kurdal E. & & Reference [2] \\
\cline { 1 - 2 } S. thermophilus & $9,01(\log \mathrm{cfu} / \mathrm{ml})$ & \\
L. bulgaricus & $8,42(\log \mathrm{cfu} / \mathrm{ml})$ & Reference [31] \\
\hline Sarvari F, Mortazavian AM, Fazeli MR & & \\
\hline S. thermophilus & $8,72(\log \mathrm{cfu} / \mathrm{ml})$ & \\
L. bulgaricus & $8,48(\log \mathrm{cfu} / \mathrm{ml})$ & \\
\hline
\end{tabular}

\section{CONCLUSION}

The utilization of yogurt as an excipient for various topical dermatological products is discussed. If such an ointment, where yogurt is used as an excipient, is manufactured by conventional methods (elevated temperatures and turbulent homogenization), under such conditions the major probiotic bacteria used for yogurt production (in this case $S$. thermophilus and L. bulgaricus) should be in the lysed state following the production of the ointment. In addition to heat and turbulent homogenization, the added antimicrobial agent(s) would also support this lysation process.

Many groups have shown that "lysed probiotics" exert favorable effects on the skin. These effects were shown to be at least as favorable as the "live forms" of the corresponding probiotics. Apart from using $S$. thermophilus and L. bulgaricus as starter cultures for yogurt production, different probiotics (starter cultures) may also be used. The corresponding yogurt samples (with different starter cultures) could perhaps be used in ointments, depending on the targeted effect to be achieved. Using yogurt as an excipient for a certain topical dermatological product could be promising for the future, since such a formulation may deliver significant amounts of; "Lysed Probiotics", "Amino Acids (amino acids make up 40\% of the skin's Natural Moisturizing Factor/NMF)", "Vitamins and fatty acids (it needs to be assessed whether the vitamins and the fatty acids are transferred from yogurt to the final formulation without degradation)" and "Minerals" to the Stratum Corneum, locally.

\section{OVERVIEW}

The utilization of yogurt as an excipient for various topical dermatological products is discussed. Yogurt contains live probiotics as such, which are shown to be exerting favorable effects in the human body. On the other hand, as cited in the above text, many groups have also shown that "lysed probiotics" also exert favorable effects in the human body and the skin locally. Using yogurt as an excipient for a certain topical dermatological product could be promising, since such a formulation may also deliver significant amounts of; Lysed Probiotics, Amino Acids (amino acids make up $40 \%$ of skin's Natural Moisturizing Factor/NMF), Fatty Acids, Minerals and Vitamins to the stratum corneum locally. We were able to reassess the proportional corresponding amounts of amino acids in the final topical formulation that were present in the yogurt samples used (unpublished results). But no further studies were done in order to determine if all the Vitamins and Fatty Acids in the yogurt sample are transferred to the ointment intact, without degradation. Further studies are needed in order to investigate the utilization of yogurt as an excipient in topical dermatological products and its corresponding clinical implications.

\section{FUNDING}

Nil

\section{AUTHORS CONTRIBUTIONS}

All the authors have contributed equally. 


\section{CONFLICT OF INTERESTS}

The author reports no conflict of interest.

\section{REFERENCES}

1. De Vuyst L, Degeest B. Heteropolysaccharides from lactic acid bacteria. FEMS Microbiol Rev 1999;23:153-77.

2. Yilmaz Ersan L, Kurdal E. The production of set-type-bioyoghurt with commercial probiotic culture. Int J Chem Eng Appl 2014;5:402-8.

3. Report of a joint food and agriculture organization of the United Nations/World Health Organization (FAO/WHO) expert consultation on the evaluation of health and nutritional properties of probiotics in food including powder milk with live lactic acid bacteria. Cordoba, Argentina; 2001.

4. Mohanty D, Ray P. Evaluation of probiotic and antimicrobial properties of Lactobacillus bulgaricus strains isolated from dairy products. Int J Pharm Pharm Sci 2016;8:230-4.

5. Sah BNP. Identification of bioactive peptides produced by synbiotic yogurt having anti-cancer properties. A thesis submitted for the degree of doctor of philosophy. College of Health and Biomedicine, Victoria University, Melbourne, Australia; 2016

6. Tufail M, Hussain S, Malik F, Mirza T, Parveen G, Shafaat S, et al. Isolation and evaluation of antibacterial activity of bacteriocin produced by lactobacillus bulgaricus from yogurt. Afr J Microbial Res 2011;5:3842-7.

7. Shigwedha N, Sichel L, Jia L, Zhang L. Probiotical cell fragments (PCFs) as novel nutraceutical ingredients. J Biosci Med 2014;2:43-55.

8. Kawatra P, Aiyappa C. Probiotics: the undervalued conquerors. Asian J Pharm Clin Res 2015;8:97-100.

9. Sivamaruthi SB, Kesika P, Chaiyasut C. A review of anti-aging properties of probiotics. Int J Appl Pharm 2018;10:23-7.

10. Kvit K, Kharchenko V. Role of gut microbiota in lipid metabolism. Asian J Pharm Clin Res 2018;11:4-8.

11. Pique N, Berlanga M, Minana Galbis D. Health benefits of heatkilled (tyndallized) probiotics: an overview. Int J Mol Sci 2019;20:1-30

12. Lew LC, Liong MT. Bioactives from probiotics for dermal health: functions and benefits. J Appl Microbiol 2013;114:1241-53.

13. Mohammedsaeed W. Characterisation of the potential of probiotics or their extracts as therapy for skin. A thesis submitted to the University of Manchester for the degree of doctor of philosophy in the Faculty of Medical and Human Sciences; 2014.

14. Gueniche A, Bastien P, Ovigne JM, Kermici M, Courchay G, Chevalier V, et al. Bifidobacterium longum lysate, a new ingredient for reactive skin. Exp Dermatol 2009;19:e1-e8.

15. Verdier Sevrain S, Bonte F. Skin hydration: a review on its molecular mechanisms. J Cosmet Dermatol 2007;6:75-82.

16. USDA National Nutrient Database for Standard Reference, Release,/Full Report (All Nutrients) 01116/Yogurt Plain Whole Milk. Available from: https://fdc.nal.usda.gov/fdc-app.html\#/ food-details/171284/nutrients. [Last accessed on 04 Jan 2019].

17. Fisberg M, Machado R. History of yogurt and current patterns of consumption. Nutr Rev 2015;73(S1):4-7.

18. Chandan RC, Gandhi A, Shah NP. Yogurt: historical background, health benefits, and global trade. In: Shah NP. Editor. Yogurt in health and disease prevention. Cambridge: Academic Press; 2017. p. 3-29.

19. Courtin P, Rul F. Interactions between microorganisms in a simple ecosystem: yogurt bacteria as a study model. Le Lait, INRA Editions 2004;84:125-34.

20. Guarner F, Perdigon G, Corthier G, Salminen S, Koletzko B, Morelli L. Should yoghurt cultures be considered probiotic? Br J Nutr 2005;93:783-6.

21. Hon A/Prof. Amanda Oakley, Department of Dermatology, Waikato Hospital, Hamilton, New Zealand; 2001. Available from: dermnetnz.org/topics/fingertip-unit/. [Last accessed on 04 Jan 2019].

22. Proksch E. The role of emollients in the management of diseases with chronic dry skin. Skin Pharmacol Physiol 2008;21:75-80.

23. Choe C, Schleusener J, Lademann J, Darvin ME. Human skin in vivo has a higher skin barrier function than porcine skin ex vivo-comprehensive Raman microscopic study of the stratum corneum. J Biophotonics 2018;11:e201700355:1-10.

24. Yeo TW, Rooslamiati I, Gitawati R, Tjitra E, Lampah DA, Kenangalem E, et al. Pharmacokinetics of L-arginine in adults with moderately severe malaria. Antimicrob Agents Chemother 2008;52:4381-7.

25. Recommended dietary allowances. 10th Edition. National Academy Press: Washington DC; 1989. p. 57. Available from: http://www.aulavirtual-

exactas.dyndns.org/claroline/backends/download.php?url=L0 51dHJpY2lvbi9Jbmdlc3Rhc0RpYXJpYXNSZWNvbWVuZGFkYX MucGRmandcidReset=trueandcidReq=RICIONUTRI. [Last accessed on 04 Jan 2019]

26. Grice EA, Segre JA. The skin microbiome. Nat Rev Microbiol 2011;9:244-53.

27. Schommer NN, Gallo RL. Structure and function of the skin microbiome. Trends Microbiol 2013;21:660-8.

28. SanMiguel AJ, Meisel JS, Horwinski JS, Zheng Q, Grice EA. Topical antimicrobial treatments can elicit shifts to resident skin bacterial communities and reduce colonization by Staphylococcus aureus competitors. Antimicrob Agents Chemother 2017;61:e00774-17:1-13.

29. Di Marzio L, Cinque B, De Simone C, Cifone MG. Effect of the lactic acid bacterium Streptococcus thermophilus on ceramide levels in human keratinocytes in vitro and stratum corneum in vivo. J Invest Dermatol 1999;113:98-106.

30. O'Neill C, Mcbain A. WO Patent 181534. The University of Manchester, GB; 2015.

31. Sarvari F, Mortazavian AM, Fazeli MR. Biochemical characteristics and viability of probiotic and yogurt bacteria in yogurt during the fermentation and refrigerated storage. Appl Food Biotechnol 2014;1:55-61. 